\title{
Relation Glasser's basic needs with hypertension in middle age: the mediating role of humor
}

\author{
$\underline{\text { Sh. Kazemi }}^{1}$, AR. Kakavand ${ }^{2}$, MR. Jalali ${ }^{2}$, HR. Javadi ${ }^{3}$
}

\footnotetext{
${ }^{1}$ Department of General Psychology, Imam Khomeini International University, Qazvin, Iran

${ }^{2}$ Department of Psychology, Imam Khomeini International University, Qazvin, Iran

${ }^{3}$ Department of Cardiology, Qazvin University of Medical Sciences, Qazvin, Iran

Corresponding Address: Shokoofe Kazemi, Imam Khomeini International University, Qazvin, Iran Tel: +98-918-5117480; Email: kazemishokoofe@gmail.com

Received: 12 Feb 2018; Accepted: 3 May 2018
}

\section{Abstract}

Background: Blood pressure disease is one of the most important risk factors for cardiovascular diseases.

Objective: The purpose of this research was to investigate the relationship between Glasser's basic needs with hypertension in the middle aged peoples by mediating variable of humor.

Methods: In the present study, descriptive-correlational research design was used. The sample consisted of 204 middle aged people who referred to Bu-Ali Sina Hospital in Qazvin (92 males, and 112 females). Purposive sampling method was utilized for collecting the data. The instruments of the present study included Sahebi adjustment scale, sense of humor questionnaire and the blood pressure information questionnaire. Data was analyzed using structural equation modeling method.

Findings: The results showed that the proposed model had an acceptable fitness. In the relationship between basic needs with blood pressure and the role of mediator of humor, the direct relationship between blood pressure and the need for belonging, fun, survival, power and freedom was significant (95\% confidence interval). Indirect relationship between blood pressure and the need for belonging, fun, survival and power was significant. Also, the direct relationship between humor and blood pressure was confirmed $(\beta=-0.55)$. Finally, in this model, the direct relationship between the need for belonging, survival, power and freedom with humor was confirmed (95\% confidence interval).

Conclusion: It can be concluded that there is a meaningful relationship between humor and blood pressure. Glasser's basic needs and, consequently the humor and their uses in dealing with stresses can reduce the blood pressure in middle aged persons.

Keywords: Glasser's basic needs, Hypertension, Humor

Citation: Kazemi Sh, Kakavand AR, Jalali MR, Javadi HR. Relation Glasser's basic needs with hypertension in middle age: the mediating role of humor. J Qazvin Univ Med Sci 2018; 22(2): 63-73. 


\title{
ارتباط نيازهاى اساسى كَلاسر با فشارخون بالا در ميانسالان: نقش واسطهاى شوخ طبعى
}

\author{
شكوفه كاظمى'، دكتر عليرضا كاكاوند'، دكتر محمدرضا جلالى '، دكتر حميدرضا جوادى"
}

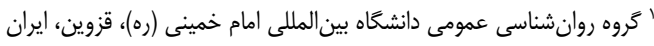

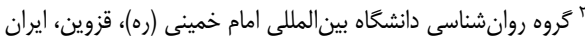

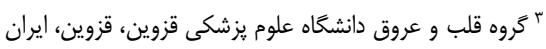

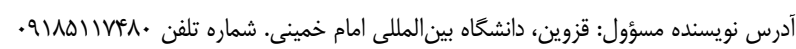
تاريخ دريافت: س/T/I

زمينه: بيمارى يُرفشارى خون از مهمترين عوامل خطر براى ابتلا به بيمارى هاى قلبى - عروقى است.

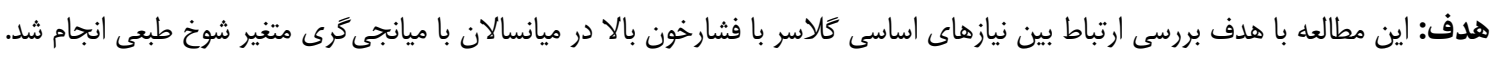

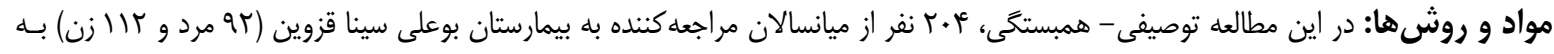

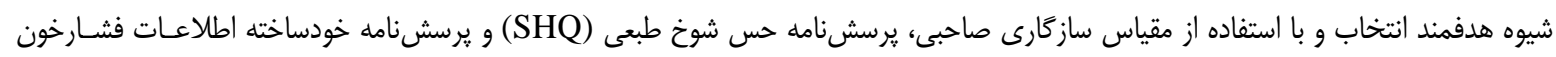

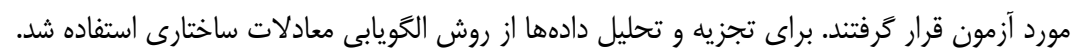

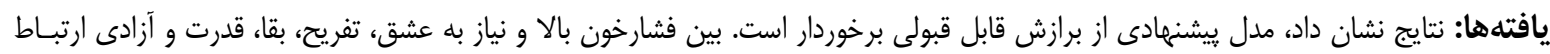

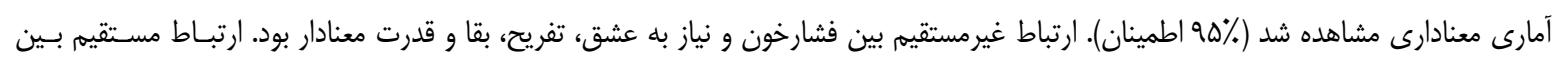

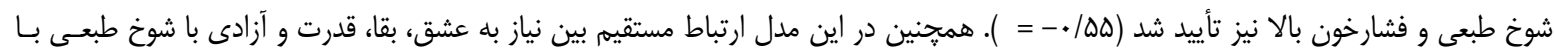

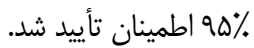

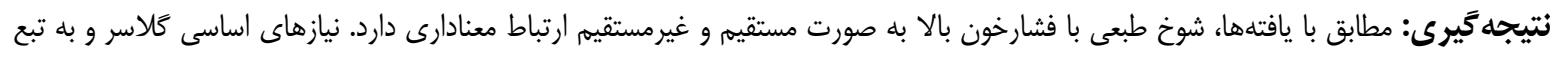

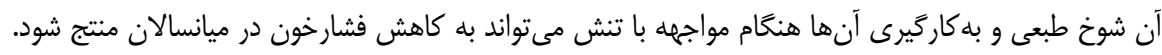

كليدوازهها: نيازهاى اساسى كلاسر، فشارخون بالا، شوخ طبعى

مقدمه:

زمانى رخ مىدهد كه فشـارخون درون رگىهـا و بـرونداد

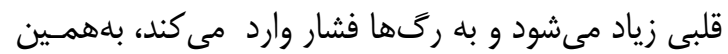

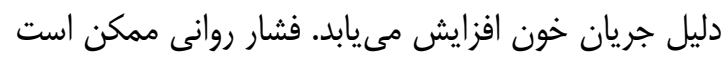

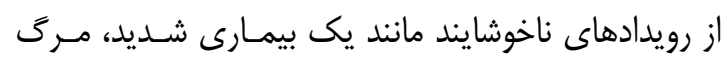

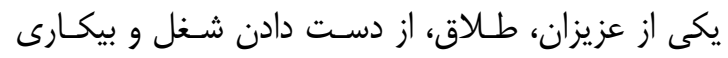

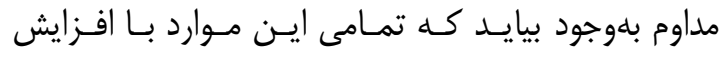

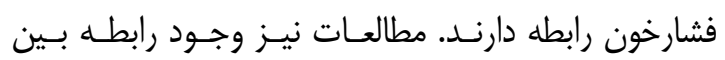

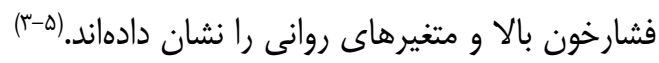

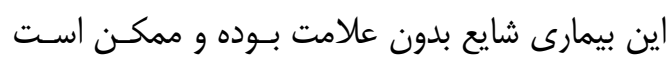

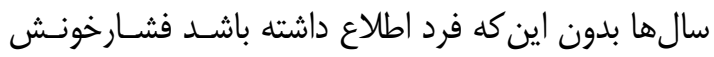

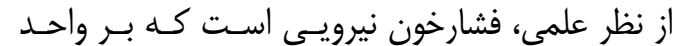

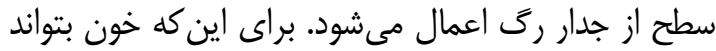

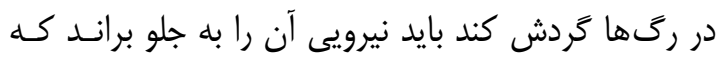

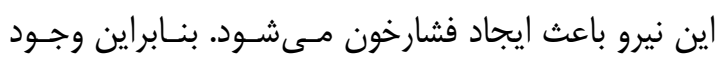

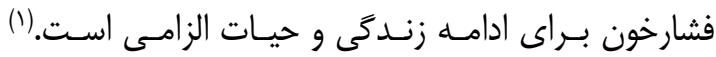

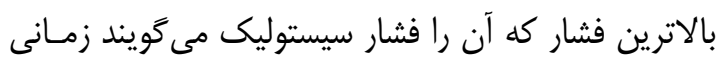

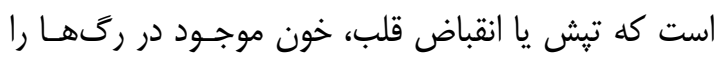

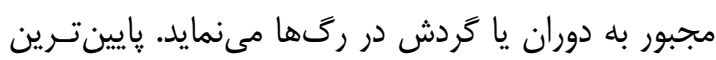

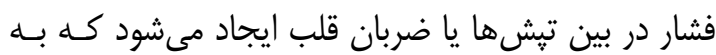

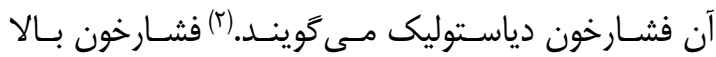


انتخابهاى آنها در قبال نيازهايشان است.(ז)

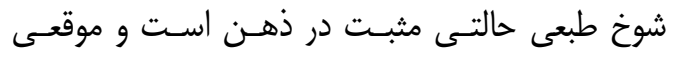

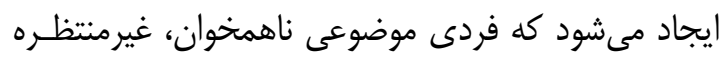

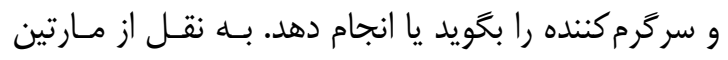

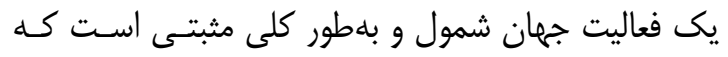

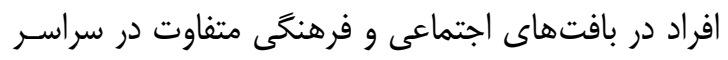

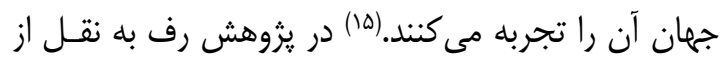

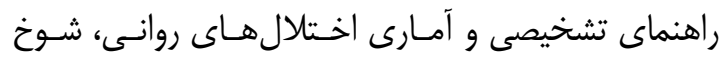

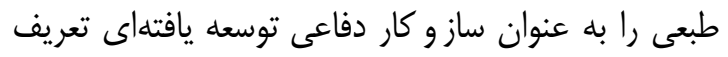

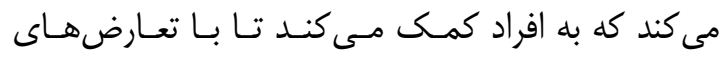

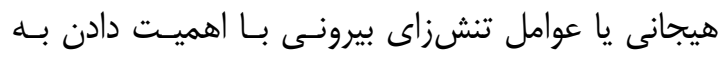
جنبههاى طنز آميز و سر گرم كننده مقابله كنند.(1)

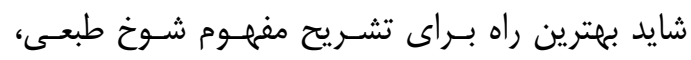

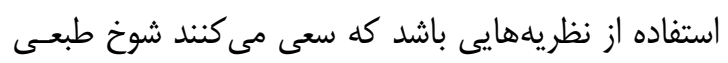
را توصيف كنند. براساس نظريه برترى، زمانى به لطيفه يا

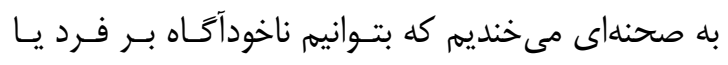

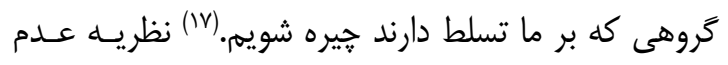
تجانس يا ناهمخوانى بر اجـزاء شـناختى شـوخى متمركـز

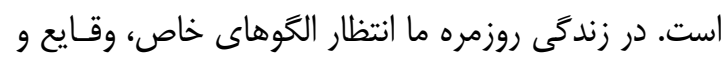
رويدادهاى خاص داريم. هنخامى مى خنديه كه اين جيزها

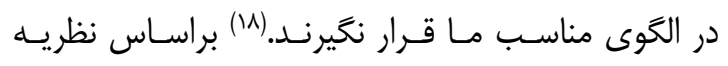

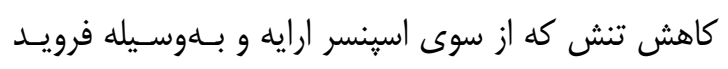

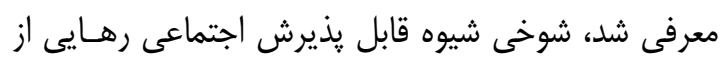

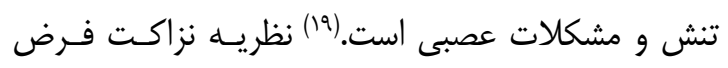

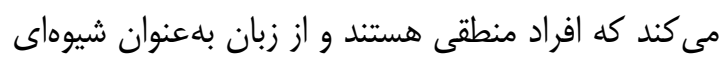
براى دستيابى به اهداف استفاده مى كنند..(r) مطالعه كرين و همكاران نشان داد، افرادى كه سـابقه

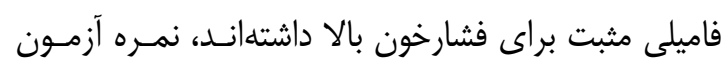

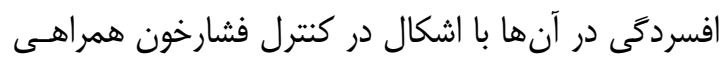

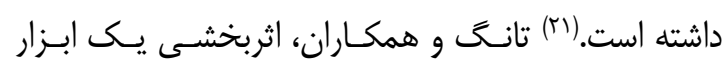

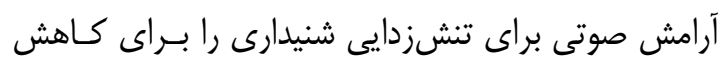

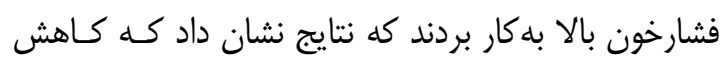

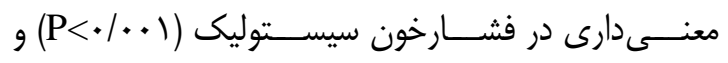

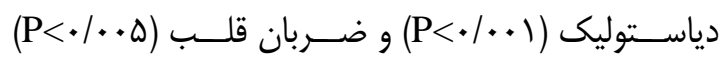

بالا باشد.(9) با توجه به نقش عوامل روانشناختى در ايجاد

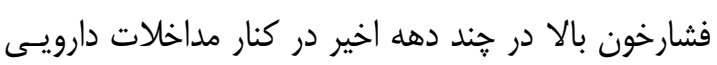

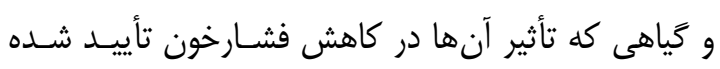

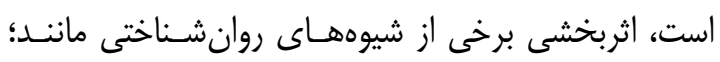

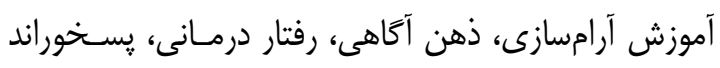

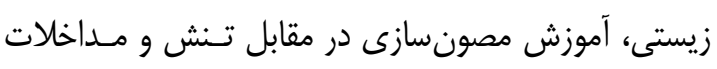

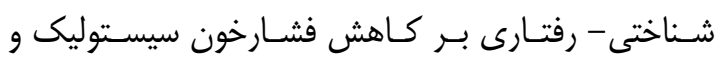

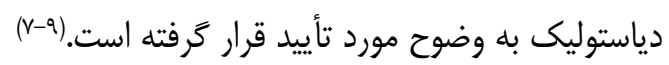

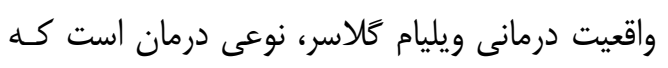

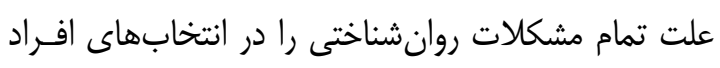

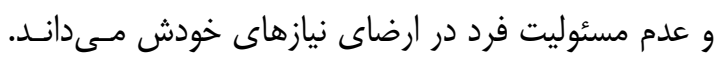

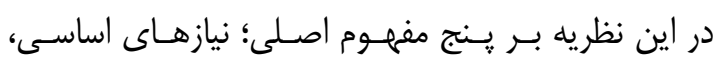

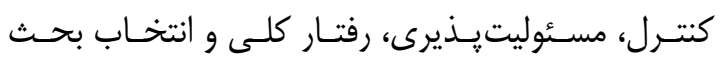

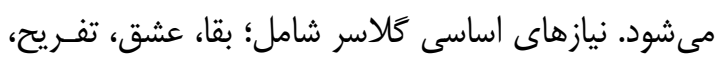

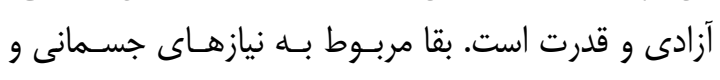

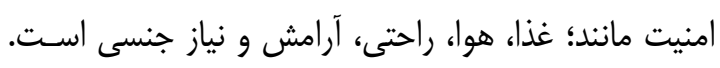

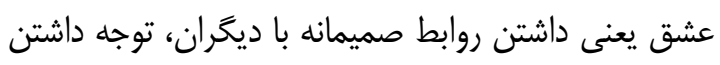

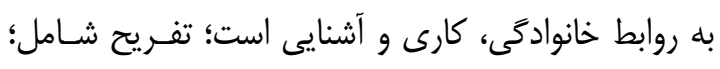

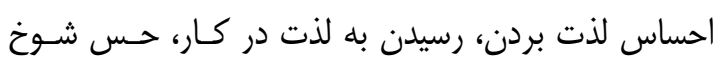

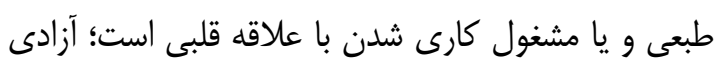

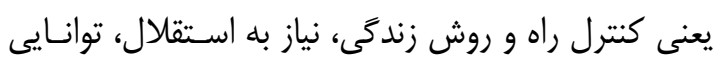

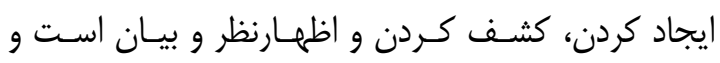

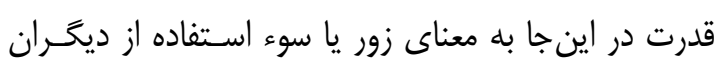

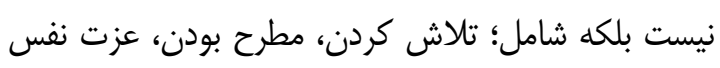

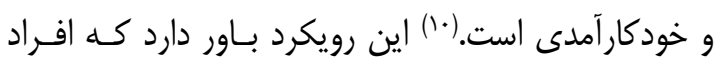

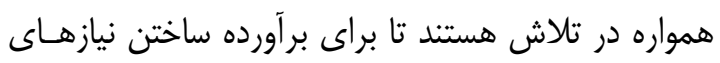
بنيادى شان، انتخابهاى مؤثرى داشته باشند.(1I)

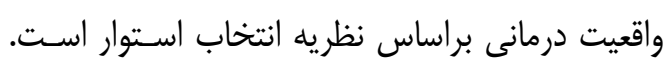

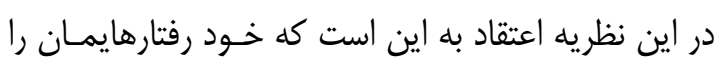

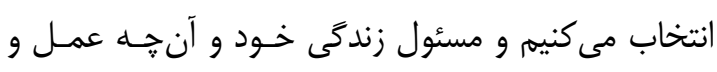

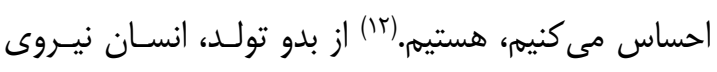

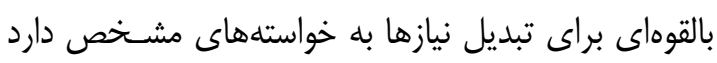

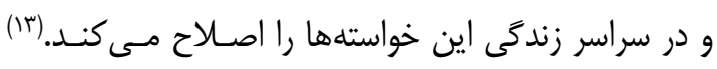

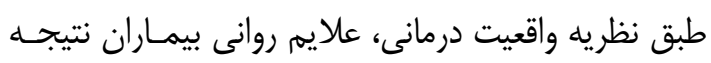




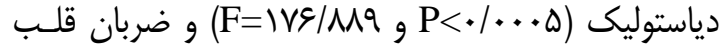

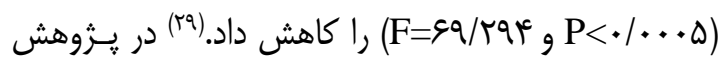
جبل عاملى و همكاران درمان شناختى - رفتارى مـديريت

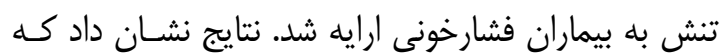
فشارخون گروه آزمايش به طور معنى دارى نسبت به كروها

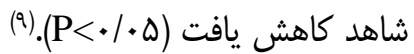

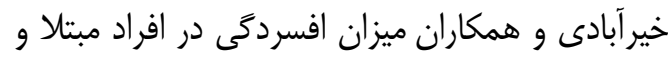

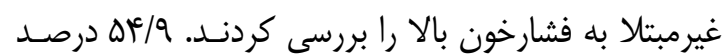
بيماران مبتلا به فشارخون بالا دهار درجاتى از افسـردخى بـى

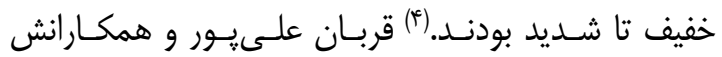

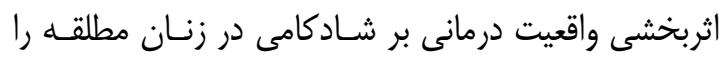

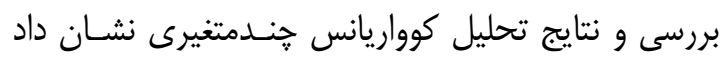

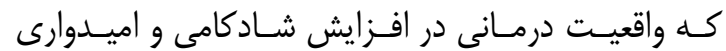

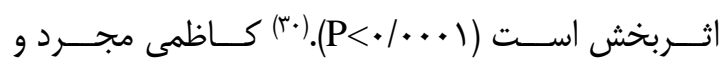

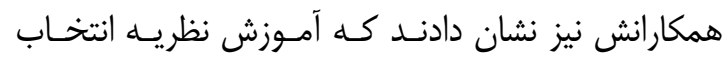

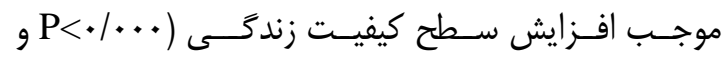

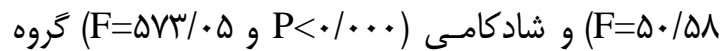

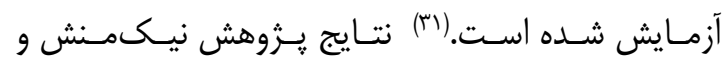

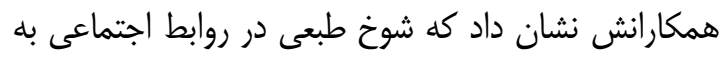

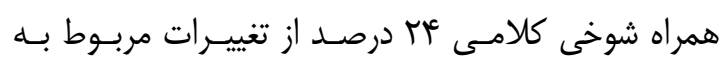

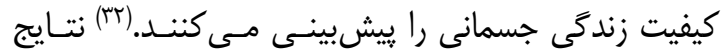

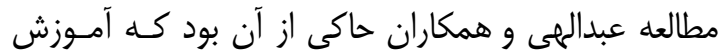

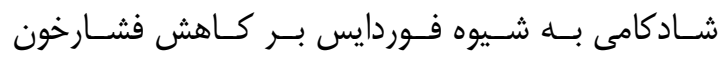

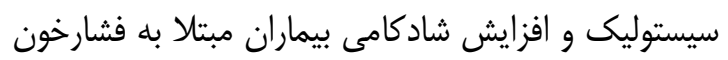

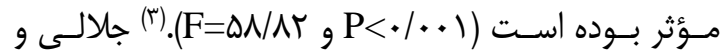

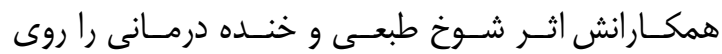

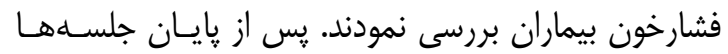

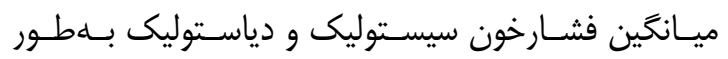

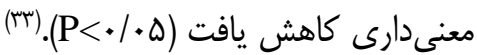

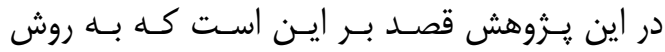

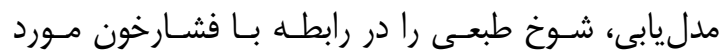

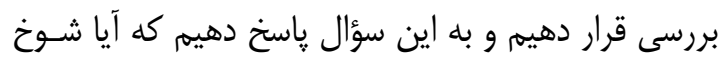
طبعى ارتباط بين نيازهاى اساسى كَلاسر و فشارخون بـالا دهائ را تحت تأثير قرار مىدهد؟ نيازي

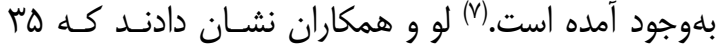

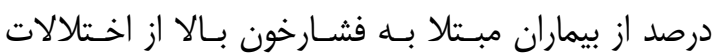

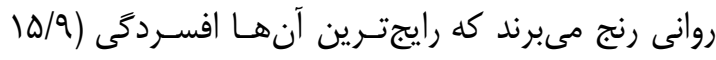

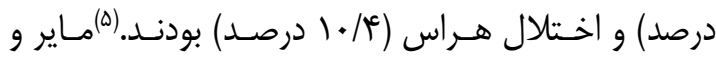
لودنسلكَ اثربخشى درمان گروهى مصونسازى در مقابـل

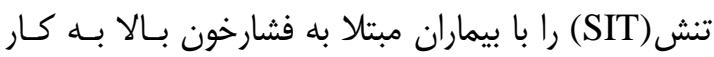
بردند. در קايان مداخله فشارخون سيستوليك و دياستوليك

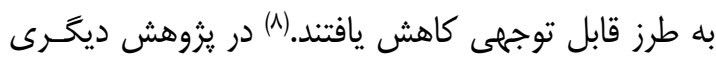
نتيجه اثربخشى درمانهاى غيردارويى بر روى سه مرد بـ بـا

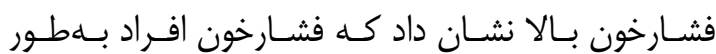
معنادارى كاهش يافت. (rT)

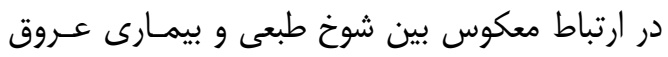
كرونرى قلب، تجزيه و تحليل ركرسيون لجستيك نشـان

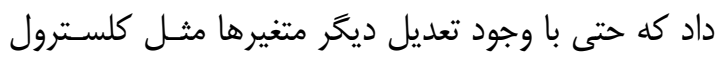

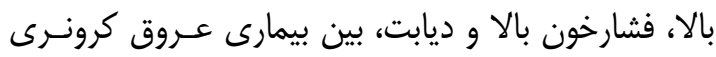

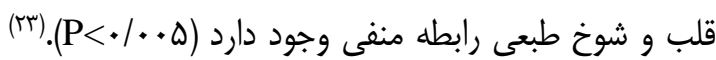
در بزوهش شريل مراجعان با اختالال تنش يس إز سانحه،

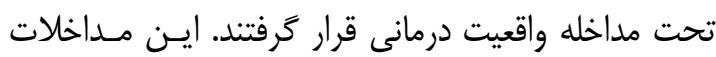

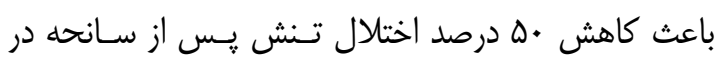

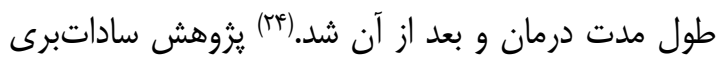

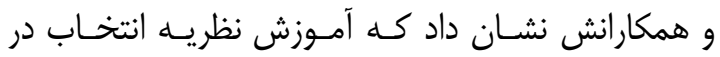
افزايش انعطافيذيرى و تابآورى زنان مطلقه تأثير داشته

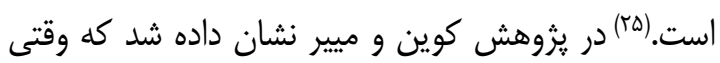

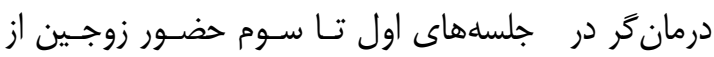

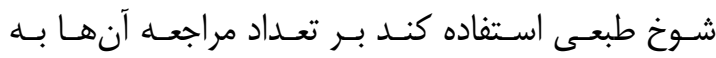

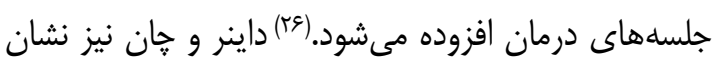

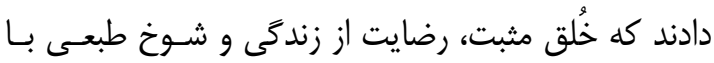
كاهش مرى و مير افراد سالم در ارتباط است. در يــروهش ادوارى و همكــاران نتــايج حـــاكى از

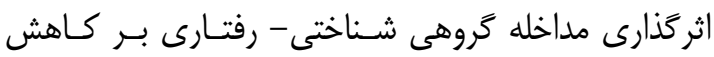

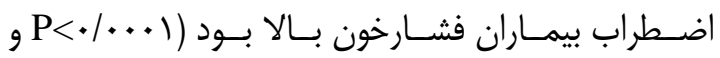

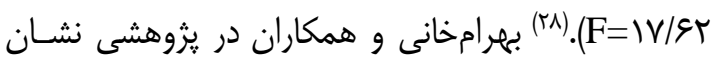
دادند كه تنشزدايى تدريجى عضلانى بهطور معنى دارى

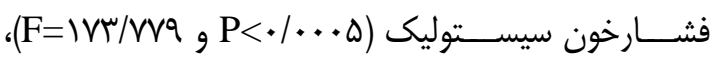


بقا و تفريح را مورد بررسى قرار مىدهد. اين يرسـشنامـهـ

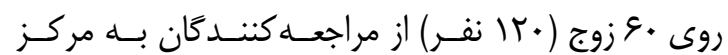

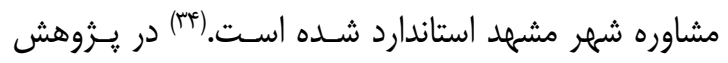
حاضر پايايى يرسشنامه به شيوه آلفاى كرونباخ براى نياز

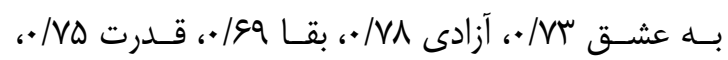

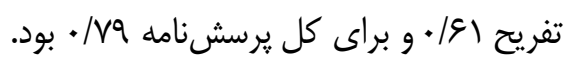

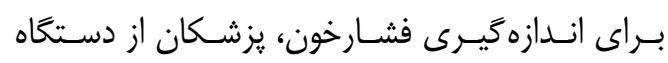

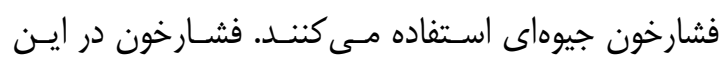

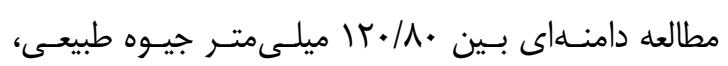

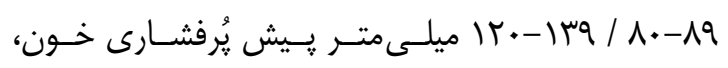

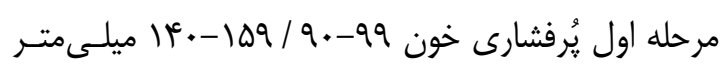

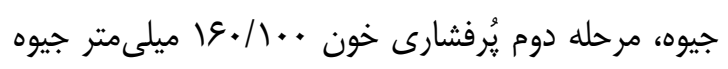

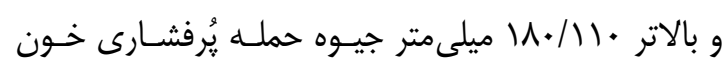

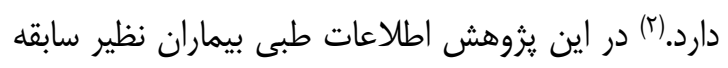

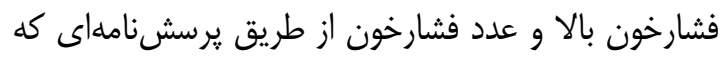

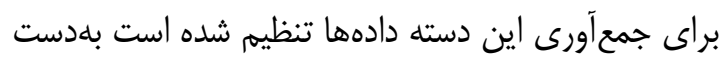

در اين يزوهش براى بلهدست آوردن شـوخ طبعى از

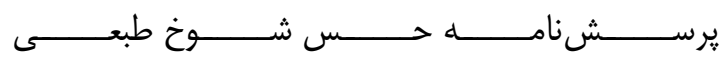
خشـوعى (Sense of humor questionnaire; SHQ)

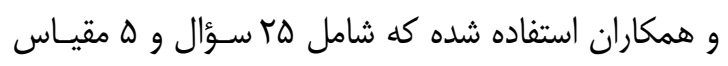

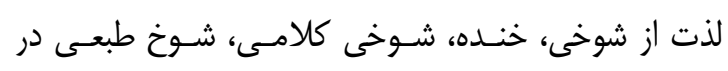

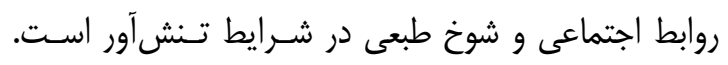

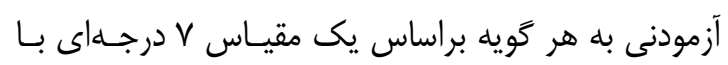

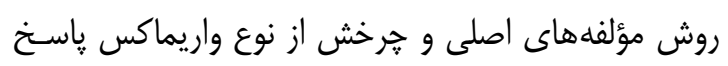

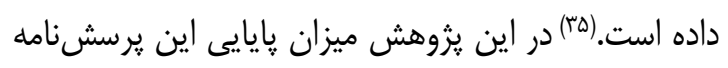

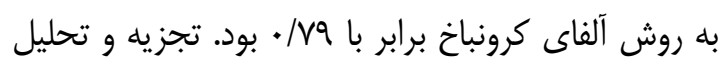

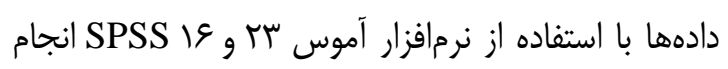

\section{بافتها:}

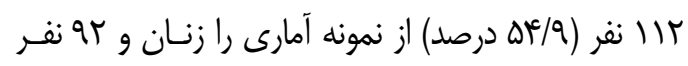

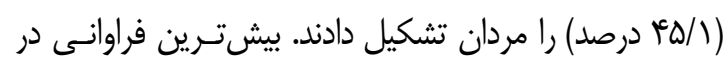

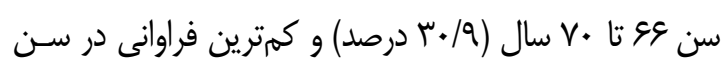

\section{دواد و ورشها:}

در اين يزوهش توصيفى - همبستخى، جامعـه آمـارى

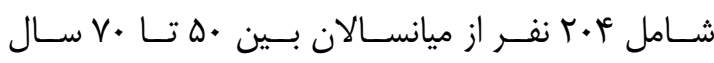

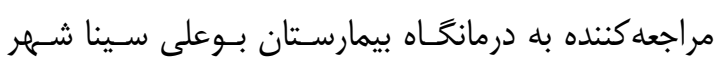

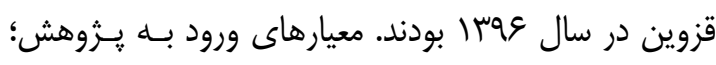

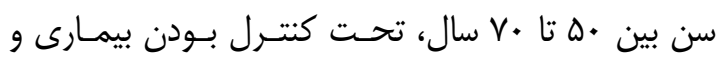

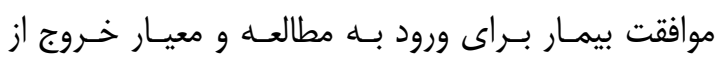

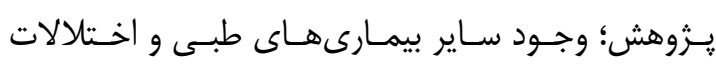

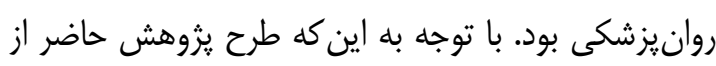

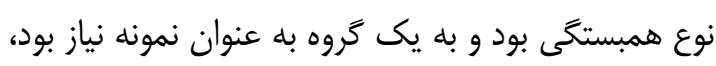

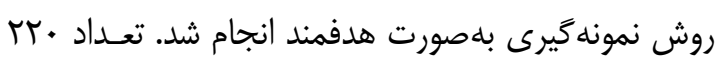

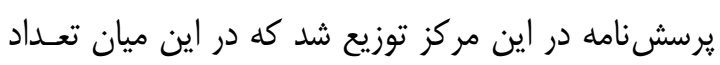
وا يرسشنامه به صورت ناقص تكميل شده بود كه كنـار

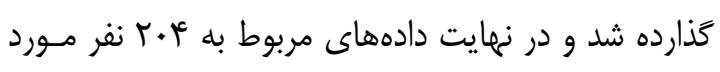

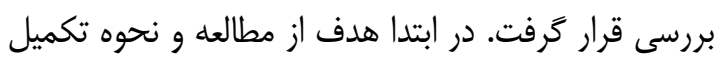

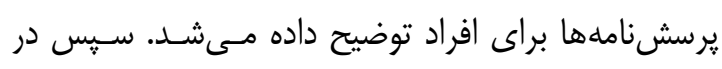

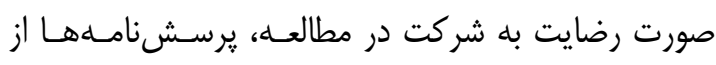

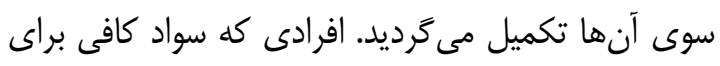

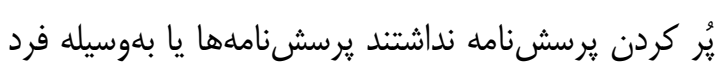

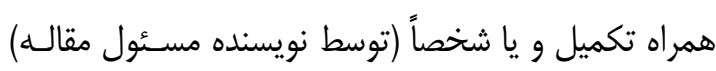
سؤالات يرسشنامهها را براى آنها باز كو مى كردم.

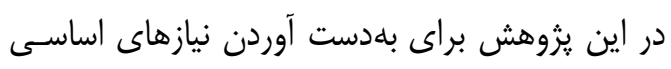

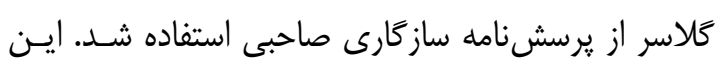

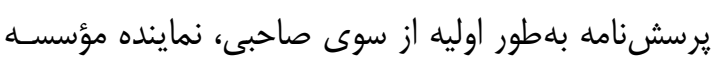

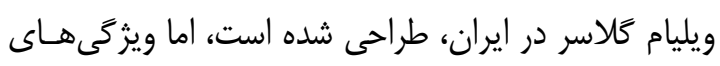

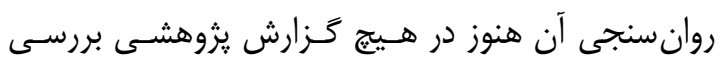

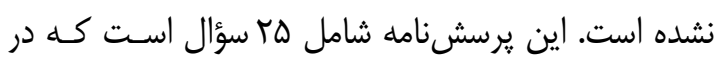

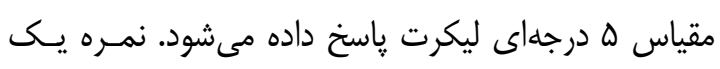

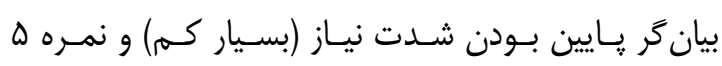

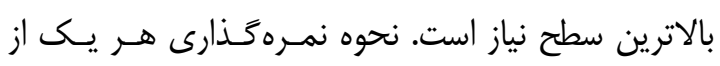

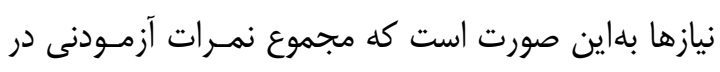

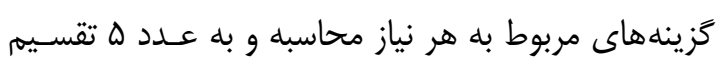

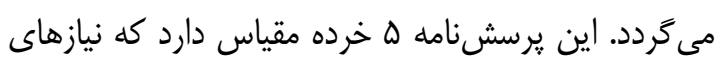

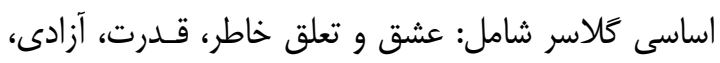


شاخصهاى برازش مدل در شكل و جدول زيـر ارايـه شــه

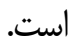

جدول r- شاخصهاى برازش مدل ارتباط نيازهاى

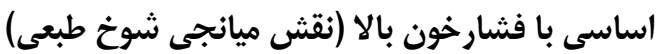

\begin{tabular}{|c|c|c|}
\hline \multicolumn{2}{|c|}{ شاخصهاى برازش } & \multirow{2}{*}{ 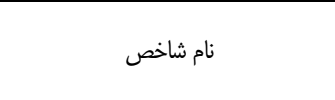 } \\
\hline حد مجاز & مقدار & \\
\hline 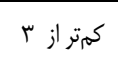 & $r / M$ & $\frac{x z}{a_{f}}$ \\
\hline كمتر از / /. &.$/ .1$ & ريشه ميانكين خطاى برآورد (RMSEA) \\
\hline بالاتر از 9/. & . /9D & برازندىى تعديل يافته (CFI) \\
\hline بالاتر از /9/. & .99 & براززندى نرم شده (NFI) \\
\hline بالاتر از /9/. & $\cdot / 9$. & نيكويى برازش (GFI) \\
\hline بالاتر از /9/. &.$/ 91$ & نيكويى برازش تعديل شده (AGFI) \\
\hline
\end{tabular}

در جدول م مقدارهاى بلهدست آمده براى اين شـاخصهـا

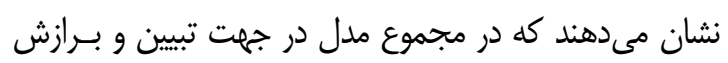

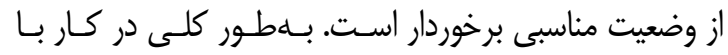

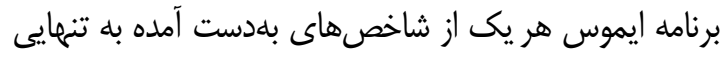
دليل برازندگى يا عدم برازندگى مدل نيستند و اين شاخصها

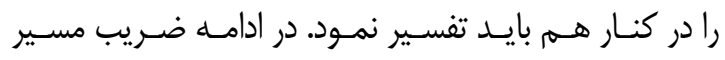

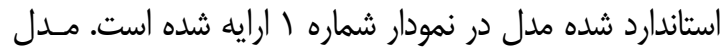

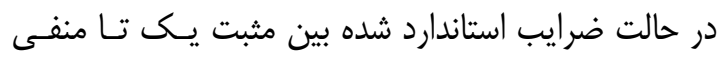

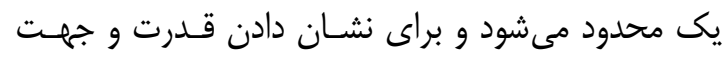
رابطه از آن استفاده مىشود.
او تا هو سال با مقدار / أ درصد است. بيشترين فراوانى

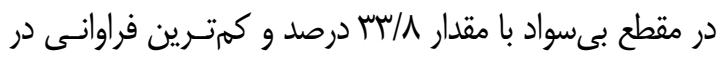

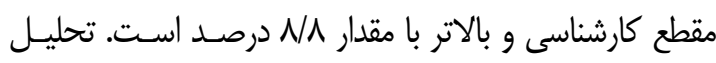

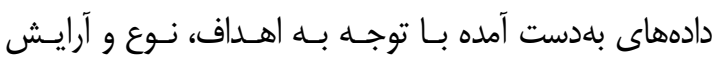

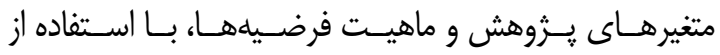

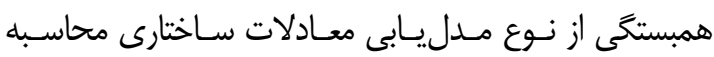

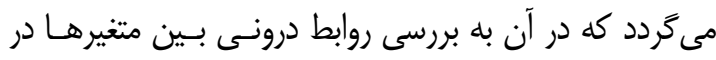
قالب كشف و تبيين مدل يرداخته مىشود.

\section{جدول ا - شاخصهاى ترايش مركزى و يراكندتى}

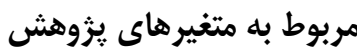

\begin{tabular}{|c|c|c|c|c|c|}
\hline كشيدَى & 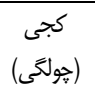 & أنحراف & ميانكين & تعداد & شاخص آمارى \\
\hline$-\cdot / T^{c}$ & $\cdot / T \Delta$ & $\cdot / \Delta T$ & $\Gamma / \uparrow \Lambda$ & $r \cdot r$ & نياز به عشق \\
\hline.$- / 41$ &.$|0|$ &.$/ \Delta V$ & $r / \cdot 1$ & $r+r^{c}$ & نياز به قدرت \\
\hline.$/ \pi f$ &.$/ 10$ &. $\mid A T$ & $r / \cdot \Lambda$ & $r \cdot r^{c}$ & نياز به آزادى \\
\hline$-\cdot / K I$ &.$/ 1 T$ &.$/ 8$. & $\Gamma / M$ & $r \cdot r^{c}$ & نياز به بقا \\
\hline.$- / \pi T$ & .110 &.$/ A T$ & $r / q$. & $r \cdot r$ & نياز به تفريح \\
\hline . &.$-- \Delta T$ & $19 / \Delta F$ & $q \varepsilon / N$ & $r+r^{c}$ & شوخ طبعى \\
\hline.$- / 41$ &.$/ D S$ & $r / .9$ & $14 / 94$ & $r \cdot r$ & فشارخون \\
\hline
\end{tabular}

در جدول بالا ميانخين، انحراف استاندارد، مقــار كجـى و كشيدگى متغيرها نشاندهنده نرمال بودن دادهها است. نتسايج مربوط به اجراى مدل بزوهش نقش ميانجى شوخ طبعى در

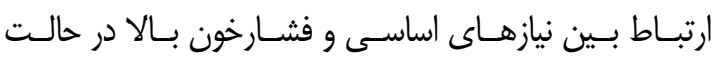

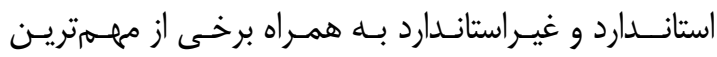

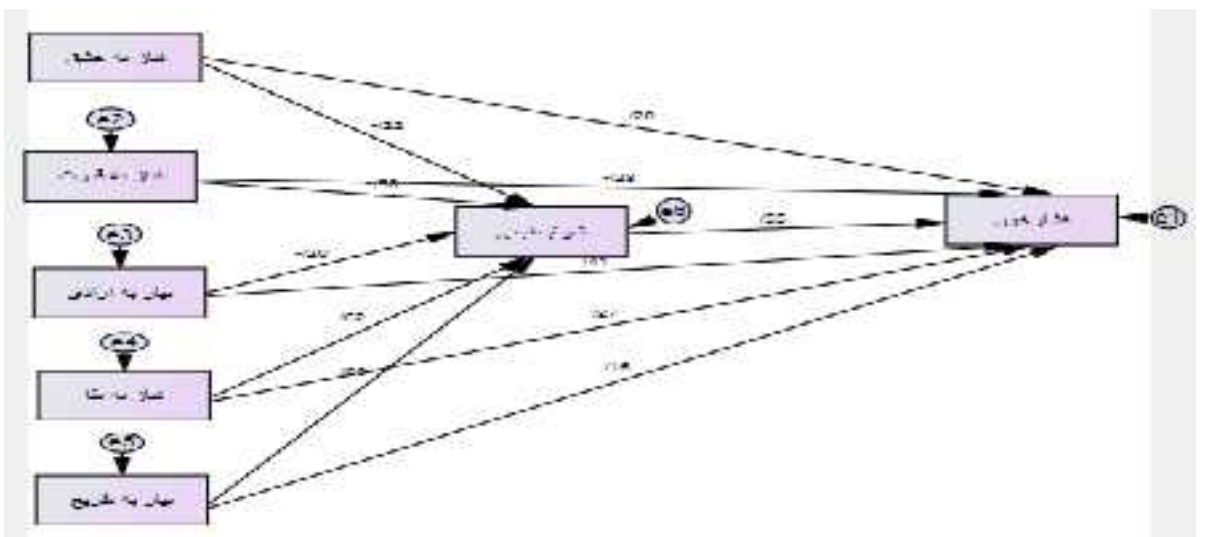

نمودار - ضرايب استاندارد شده مسيرهاى مدل نهايى 


\section{جدول ب- ضرايب و معنادارى اثر مستقيم و غيرمستقيم نيازهاى اساسى بر فشارخون بالا (نقش ميانجى شوخ طبعى)}

\begin{tabular}{|c|c|c|c|c|c|c|}
\hline خطاى استاندارد & تى & م استاندارد شده & ضريب استاندارد نشده & نوع اثر & متغير ييش بين & متغير ملاك \\
\hline$\cdot / \pi T$ & $-V / .9$ &.$-|r|$ & $-1 / \Delta S$ & مستقيم & نياز به عشق & شوخ طبعى \\
\hline .1 .9 & $T / N T$ & $.1 \cdot 1$ & .1 .4 & مستقيم & نياز به تفريح & شوخ طبعى \\
\hline.$/ 4 T$ & 19/9. & .191 & $\kappa / \widetilde{\mu}$ & مستقيم & نياز به بقا & شوخ طبعى \\
\hline 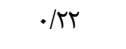 & $-\mid N / F \Lambda$ & $-\cdot / \Delta V$ & $-4 / l f$ & مستقيم & نياز به قدرت & شوخ طبعى \\
\hline$\cdot|r|$ & $-8 / \Delta T$ &.$- / r$ & $-1 / 49$ & مستقيم & نياز به آزادى & شوخ طبعى \\
\hline T & $8 / 4 \Lambda$ & $\cdot / r$. & $7 / .9$ & مستقيم & نياز به عشق & فشارخون \\
\hline$\cdot / N \Delta$ & Q/\&. &.$/ 10$ & $F / r$ & مستقيم & نياز به تفريح & ف فشارخون \\
\hline.$/ 49$ & $-\Delta / V q$ &.$- / T r$ & $-r / \Lambda \Delta$ & مستقيم & نياز به بقا & فشارخون \\
\hline.$/ A V$ & $-8 / \cdot 4$ &.$- / T \Lambda$ & $-r / M$ & مستقيم & نياز به قدرت & ف شارخون \\
\hline . & $I r / \Delta V$ &.$/ 41$ & T/RT & مستقيم & نياز به آزادى & فشارخون \\
\hline.$/ 19$ & $-\Delta / \cdot r$ &.$- / \pi r$ & $-\Delta / 1 f$ & غيرمستقيه & نياز به عشق & فشارخون \\
\hline 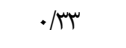 & $-r / M \Lambda$ &.$-|4|$ & $-Y / N \Delta$ & غيرمستقيه & نياز به تفريح & فشارخون \\
\hline.$/ 11$ & $-f / l f$ &.$- / 1 \mathrm{~V}$ & $F / 4 \Lambda$ & غير مستقيم & نياز به بقا & فشارخون \\
\hline$\cdot|r|$ & $-8 / 1 f$ &.$- / 49$ &.$- / \Delta S$ & غير مستقيم & نياز به قدرت & فشارخون \\
\hline.$/ \cdot r$ &.$- / 91$ &.$- / .+4$ & $-r / M$ & غيرمستقيم & نياز به آزادى & فشارخون \\
\hline$\cdot / 4 \Lambda$ & $-r / r \Delta$ & $-\cdot / \Delta \Delta$ & $-\cdot|\wedge|$ & مستقيم & شوخ طبعى & فشارخون \\
\hline
\end{tabular}

شده در ارتباط مستقيم بين شوخ طبعى و فشارخون بـالا نيـز مورد تأيبد قرار ترفت.

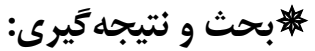

نتايج مطالعه حاضر نشان داد كه ارتباط مستقيهم بـين

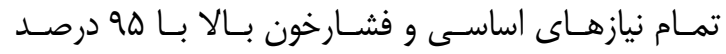

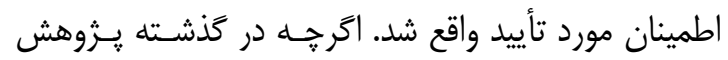

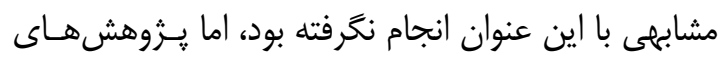

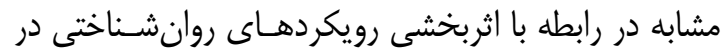

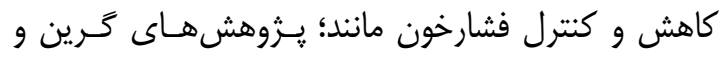

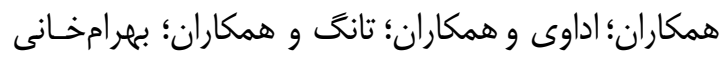

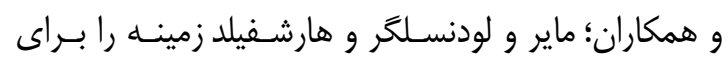

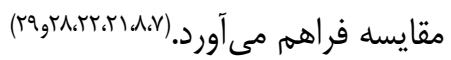

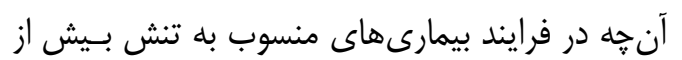

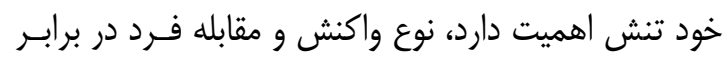

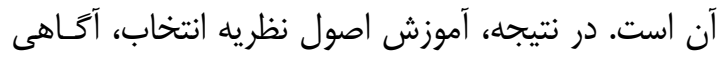

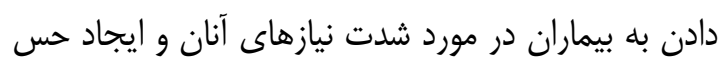

جدول فوق نشان مىدهد كه بين نياز به عشق و شوخ طبعى

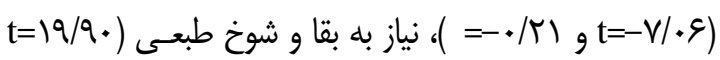

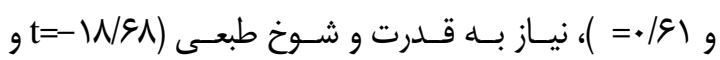

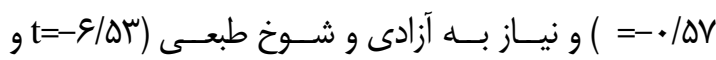

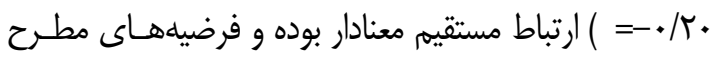

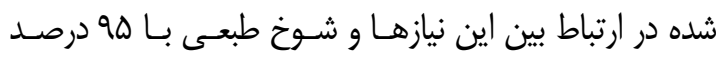

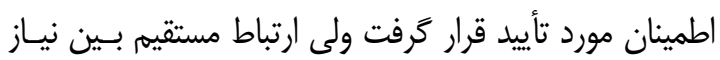
به تفريح و شوخ طبعى معنادار نبود. بين نياز به عشق، تقريح، بقا، قدرت و آزادى با فشـارخون

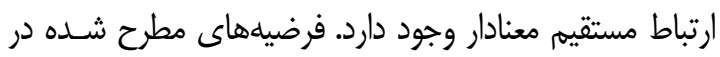

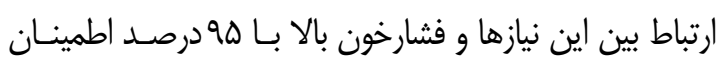

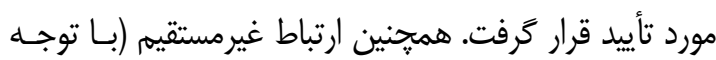
باه نقش ميانجى شوخ طبعى) بين نياز به عشق، تفريح، بقاط إنساو

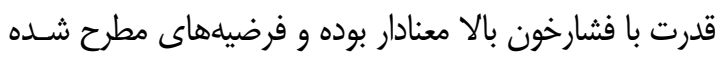

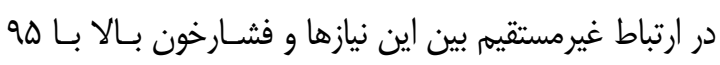

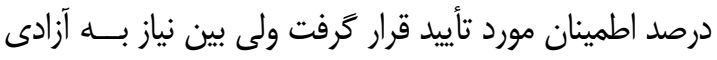

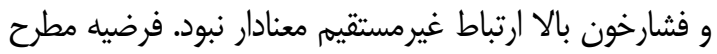


تأييد مىنمايد. نتيجه حاصل با يافتـهـــاى يـروهشهــاى

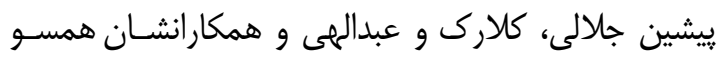

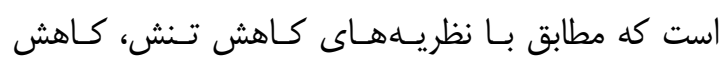

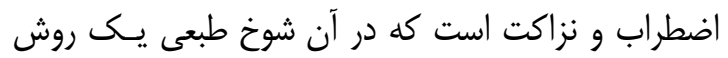

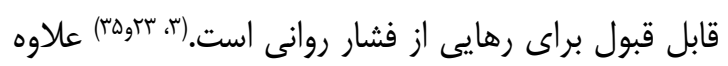

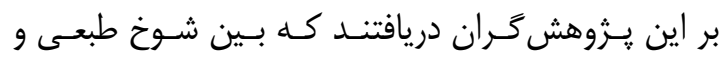

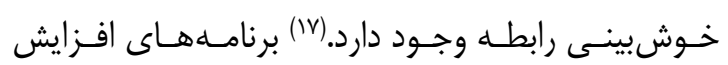

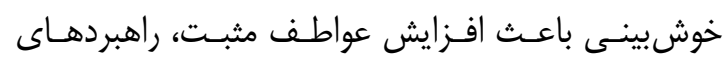

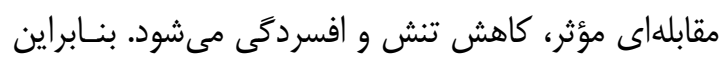

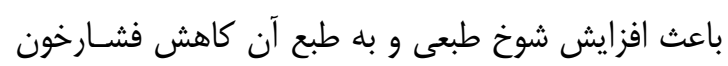

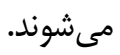

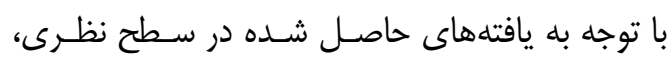

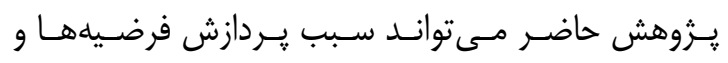

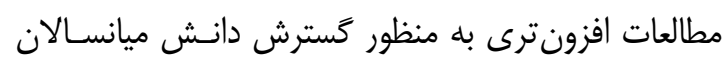

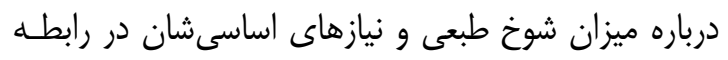

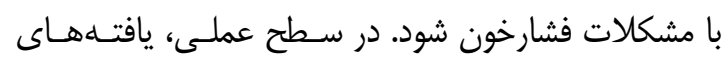

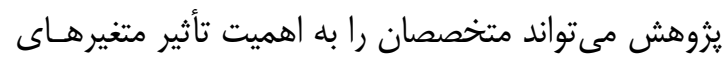

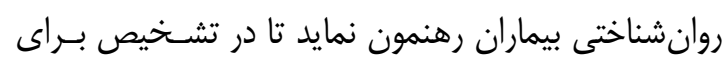

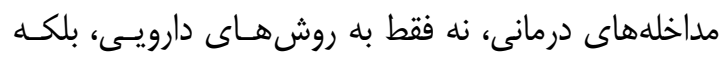
توجه اساسى خود را به شـرايط بهداشـت روانسى بيمـاران معطوف كنند.

محدوديتهاى يزوهش حاضر در ايـنـــهـ بسـيارى از

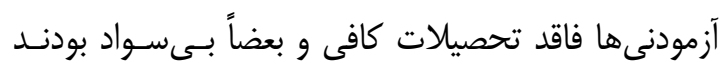

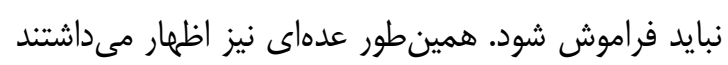

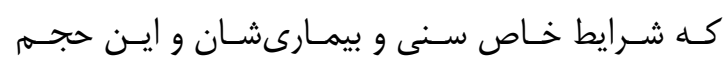

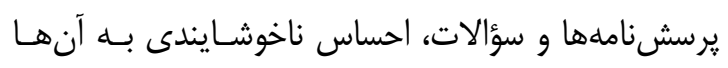

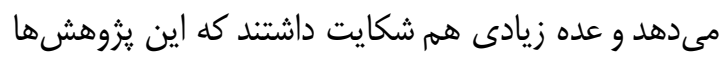

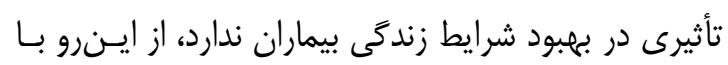

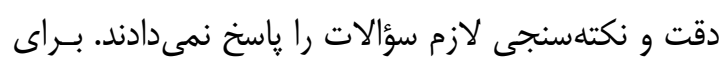

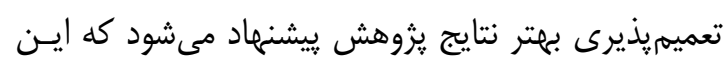

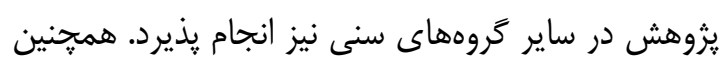

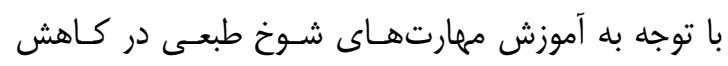

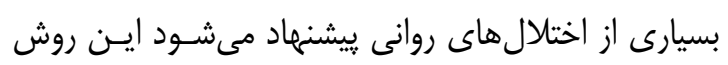
در مراكز توانبخشى و بيمارستانهـا مـورد اسـتفاده قـرار

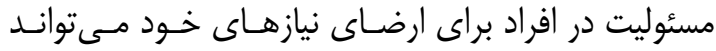

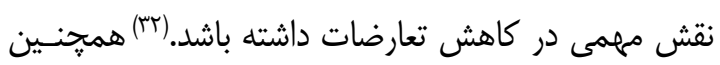

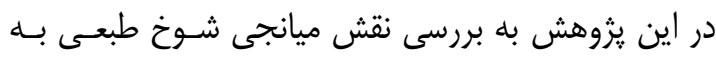

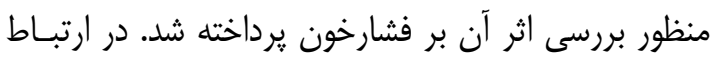

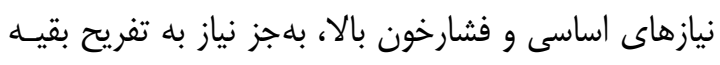
نيازها با شوخ طبعى ارتباط معنى دارى داشتند كه با با نتسايج

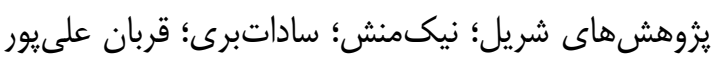

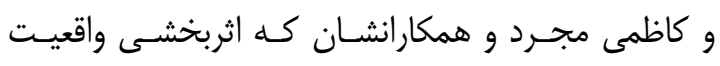

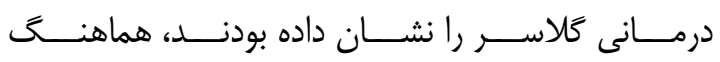

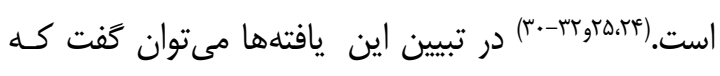

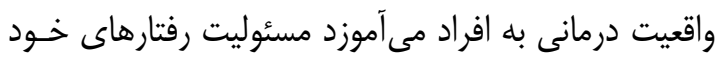

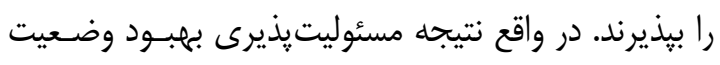

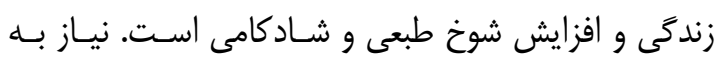
تفريح شامل احساس لذت بردن است. كاهى ايـن تمايـل

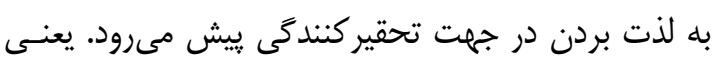

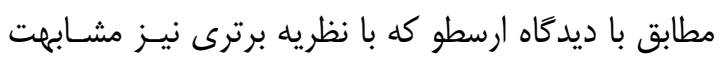

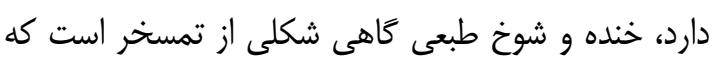

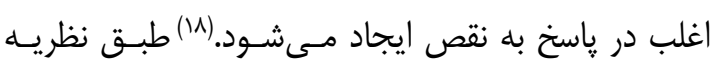

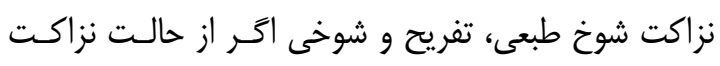

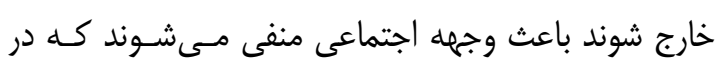

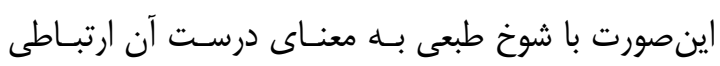
ندارند. در اين يزوهش به بررسى ارتباط غيرمستقيم نيازهاى

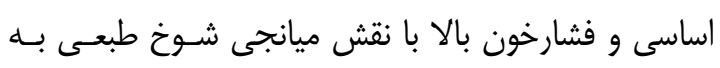

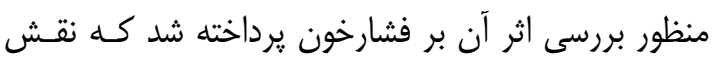

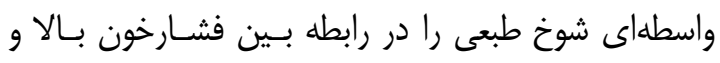

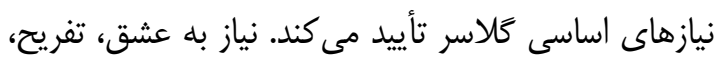

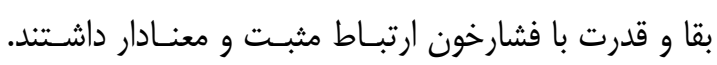

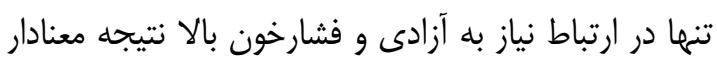

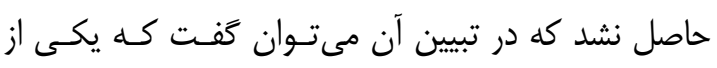

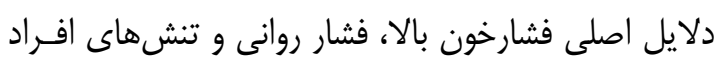

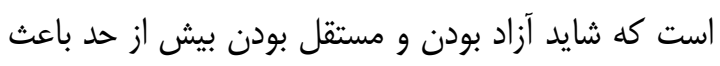

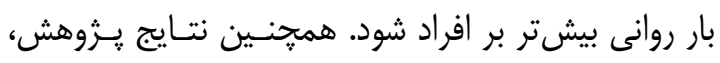

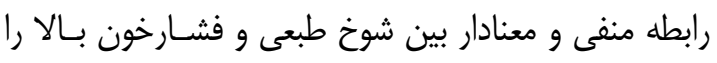


E, Denhaerynck K, Wuyts W, Belge C, et al. Emotional symptoms and quality of life in patients with pulmonary arterial hypertension. J Heart Lung Transplant 2014; 33(8): 800-8. doi: 10.1016/j.healun.2014.04.003.

7. Tang HY, Harms V, Vezeau T. An audio relaxation tool for blood pressure reduction in older adults. Geriatr Nurs 2008; 29(6): 392401. doi: 10.1016/j.gerinurse.2008.02.003.

8. Maier SF, Laudenslager M. Stress and health. J Research in Personality 2008; 15: 221-31.

9. Jabel Ameli S, Neshatdoost HT, Molavi H. The effectiveness of cognitive-behavioral stress management on quality of life and hypertension in patients with hypertension. J Kurdistan Univ Med Sci 2011; 15: 88-97. [In Persian]

10. Glasser W. Choice theory: a new psychology of personal freedom. Translated by: Firoozbakht M. 1st ed. Tehran: Rasa; 2016. 43-65. [In Persian]

11. Prochaska JO, Norcross JC. Theories of psychotherapy. Translated by: Seyed Mohammadi Y. 11th ed. Tehran: Ravan; 2012. [In Persian]

12. Tadayon M, Mohammadi Arya A, Lotfi H. The efficiency of reality therapy instruction upon the rate of life's qualification and marital conflicts of addicted spouses. J Basic Appl Sci Res 2013; 3(9): 482-6.

13. Shokri K, Aliabedi J, Saleh M, Etivand M, Fathi P. Effect of reality therapy interventions by group work on reducing the anxiety behavior in adolescents. Caspian Sea J 2016; 10(1): 620-5.

14. Farrokhzad T. A comparative study and relationship between three types of age differences between couples, five essential requirements of Glasser and marital adjustment. Thesis for Masters degree,

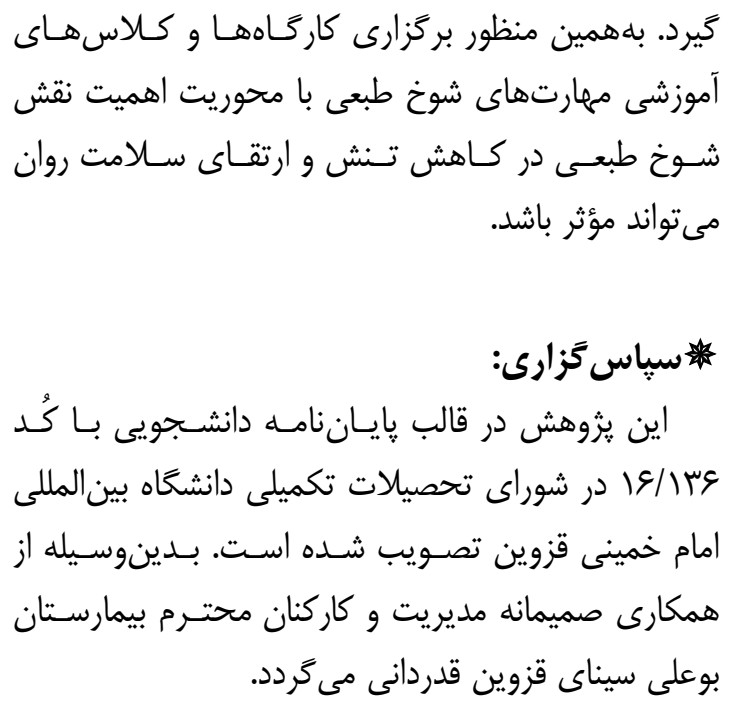

1. Moradmand S, Mousavi M. Hypertension what everyone should know.1st ed. Tehran: Timur Zadeh; 2003. 10-20. [In Persian]

2. Longo D, Kasper D, Jameson L, Fauci A. Harrison principles of internal medicine. Translated by: Naeemi T, Heidary Sh, Taherian M, Bahadoran P, Qaderi A. Tehran: Mansour; 2015. [In Persian]

3. Abdollahi Sh, Mehrabizadeh HM, Sudani $M$. The effect of happiness training on blood pressure and happiness in patients with blood pressure. J Social Psychology 2013; 7(23): 61-79. [In Persian]

4. Kheirabadi GR, Bagherian Sararoudi R, Masaeli N, Zonary R. Comparison of depression rates between subjects with and without hypertension. J Res Behav Sci 2013; 9(5): 350-7. [In Persian]

5. Lowe B, Grafe K, Ufer C, Kroenke K, Grünig E, Herzog W, et al. Anxiety and depression in patients with pulmonary hypertension. Psychosom Med 2004; 66(6): 831-6. doi: 10.1097/01.psy.0000145593. 37594.39.

6. M M Vanhoof J, Delcroix M, Vandevelde 
Tehran: Al-Zahra University; 2013. [In Persian]

15. Bakhshipour B. Humor styles and marital conflicts in married college students. J Counseling Res 2016; 14(55): 23-39. [In Persian]

16. Ghalebihajivand R, Ahmadi AJ, Kakavand AR. Study of humor styles as moderators of communication between five personality factors and general health. Behav Sci 2013; 6(1): 79-85. [In Persian]

17. Khoshouei MS. Psychology of humor. 1st Ed. Esfahan: Kankash; 2008. [In Persian].

18. Ghalebihajivand R. Construction and validation of styles of humor questionnaire in students. Thesis for Masters degree, International Qazvin University; 2011. 100. [In Persian]

19. Vafai Z, Askarizadeh G, Rahmati A. The relationship between excitement, humor and religious attitude with death anxiety. Ravanshenasi-va-Din 2011; 4(3): 49-68. [In Persian]

20. Savoglou V, Scario C. Humor styles questionnaire: personality and educational correlates in Belgian high school and college students. Eur J Personality 2002; 16(1): 4354. doi: 10.1002/per.430.

21. Grewen KM, Girdler SS, Hinderliter A, Light KC. Depressive symptoms are related to higher ambulatory blood pressure in people with a family history of hypertension. Psychosom Med 2004; 66(1): 9-16. doi: 10. 1097/01.PSY.0000106881.60228.16

22. Pickering TG, Harshfield GA, Kleinert HD, Blank S, Laragh JH. Blood pressure during normal daily activities, sleep and exercise. Comparison of values in normal and hypertensive subjects. JAMA 1982; 247(7): 992-6.

23. Clark A, Seidler A, Miller M. Inverse association between sense of humor and coronary heart disease. Int J Cardiol 2001; 80(1): 87-8. doi: 10.1016/S0167-5273(01) 00470-3.

24. Prenzlau S. Using reality therapy to reduce PTSD- related symptoms. Int J Reality Therapy 2006; 25(2): 23-30.

25. Sadat Bari N, Bahrinian SA, Azargoon H, Abedi H, Aghaei F. The effectiveness of reality therapy on resiliency of divorced women in Neyshabour city. Int Res J Appl Basic Sci 2013; 6(2): 160-4.

26. Kevin J, Meyer, MS. The relationship between therapists use of humorand therapeutic alliance. Thesis for Ph.D degree, Ohio State University; 2007. 87.

27. Diener ED, Chan MY. Happy people live longer: subjective well-being contributes to health and longevity. Appl Psychol-Hlth We 2011; 3(1): 1-43. doi: 10.1111/j.1758-0854. 2010.01045.x.

28. Adavi A, FathiMarghmalaki R, Madmoli Y, Fathi Marghmalaki R, Madmoli M. The effect of stress management on anxiety of females with hypertension. Iran J Nurs Res 2016; 11(5): 7-12. [In Persian]

29. Bahram Khani M, AliPour A, Janbozorgi M, Barzegar Ghazi K. Effectiveness of muscle progressive relaxation on perceived stress in patients with essential hypertension. Clin Psychol-Sci PR 2011; 3(1): 79-88.

30. Ghorbanalipour M, Najafi M, Alirezalo Z, Nasimi M. The effectiveness of reality therapy on happiness and hope in divorced women. Family Counseling Psychotherapy 2015; 4(2): 297-317. [In Persian]

31. Kazemi mojarad M, Bahreynian AM, Mohammadi arya A. Impact of training choice theory on quality of life and happiness of people quitting drugs. Iran J Health Educ Health Promot 2014; 2(2): 165-74. [In 


\section{Persian]}

32. Nikmanesh Z, Khosravi M, Hasanzade Z. Relationship of humor sense with quality of life in cancer patients. Toloo e Behdasht 2015; 13(3); 31-41. [In Persian]

33. Jalali SF, Kheirkhah F, Haji Ahmadi M, Seifi Zarei B. Effect of laughter therapy on blood pressure patients with essential hypertension. J Babol Univ Med Sci 2009; 10(5): 35-40. [In Persian]
34. Owladi Z. Effectiveness of group therapy based on reality therapy in reducing boredom and increasing marital satisfaction among married women. Thesis for Masters degree, Mashhad Ferdowsi University; 2012. 80. [In Persian]

35. Khoshouei MS, Oreizy Samani HR, Aghaei A. Construction and validation of sense of humor questionnaire. Psychological Res 2009; 12(1-2): 26-39. [In Persian] 